\title{
"Effectiveness Of Cfg Pile-Slab Shape On Smooth Soil For Supporting Excessive-Pace Railway Embankment"
}

\author{
Rajni Sharma ${ }^{1}$, Prince Rathod ${ }^{2}$, Dr. Manish Sharma ${ }^{3}$ \\ ${ }^{1}$ M.Tech Student, PI.T, Parul University, Vadodara, Gujarat, India \\ ${ }^{2}$ Assistant Professor, PI.T, Parul University, Vadodara, Gujarat, India \\ ${ }^{3}$ Properitor of Geo Engineering Services, Vadodara, Gujarat, India \\ ${ }^{1}$ me.rajnisharma@yahoo.com
}

Article History: Received: 11 January 2021; Accepted: 27 February 2021; Published online: 5 April 2021

\begin{abstract}
Reducing the settlements of smooth foundation efficiently is a crucial problem of excessive-pace railway creation in China. The new CFG pile-slab structure composite foundation is a floor remedy method that is carried out on CFG pile basis and pile-slab structure composite basis. Based on the revel in of constructing Beijing-Shanghai excessive-pace railway in China, the settlement-controlling effect, the settlement distribution legal guidelines and 3 key influence elements for structural shape of latest CFG pile-slab structural foundation are studied by the use of physical model exams and numerical simulations. The research results on this look at imply that the piles and soil bearing capacities of the new CFG pile-slab shape can be positioned into complete play due to the "load dispensing" function of slabs. The settlement decreasing effect of the new CFG pile-slab shape is first rate and can meet the requirements of high-pace railway creation. The affected location of engineering load has a depth over 18.Seventy five $m$ and horizontal period of 7.Five $m$ nearing the embankment slope toe. The parametric observe presents the optimalizing structural form for high-quality agreement-controlling effect. The bodily version test results display precise concordance with the numerical simulation effects. The mixture of bodily version assessments and numerical simulations justifies the usage of this version in geotechnical engineering practices.

Keywords-. Soft Soils, CFG (Cement Fly Ash Gravel) Pile, Expansive soil; Lateral loading..
\end{abstract}

\section{Introduction}

With the speedy growing visitors needs, increasingly more high-pace railways are being constructed in China. The allowable maximum agreement of Chinese high-pace railway is the most crucial key production controlling thing in railway embankment creation.

[1]. When constructing high-speed railway in coastal tender soil foundation, not unusual basis remedy era can't meet the settlement controlling requirement of high-pace railway. Therefore, the floor development techniques together with composite basis are often followed and studied in latest years [2-10]. Jiang et al. [11] provided a numerical analysis to analyze the pile-slab supported embankment, and the end result shows the share of theload carried by the soil is small. Thus, it cansignificantly reduce the settlement and the stress

transfer from the soil to the piles. Messioud et al. [12]presented a comparison between rigid piles and pilefoundations. It has concluded the influence of themattress stiffness, the geometrical configuration, andhead/tip fixity conditions on the dynamic response ofthe foundation system. Han and Bhandari [13] studiedthe stresses and deformations of geogrid-reinforcedembankments over piles. This study found thesettlements of geogrid-reinforced embankments overgeosynthetic piles are $20-30 \%$ smaller than pile

supported embankments. Okyay et al. [4] presented anumerical analysis to analyze the impedance functionsof slab foundations with rigid piles. The study hasformulated the stress change laws for rigid piles. Chenet al. [14] discussed the influences of pilingarrangement of the CFG pile composite foundation. Theresults show that the pile-soil stress ratio and the loadsharingratio can be adjusted through setting up cushionthickness. Shen et al. [9] set up a three-dimensionalsimulation model of CFG pile foundation to investigatethe influence of different cushion thicknesses on thedeformation of CFG pile foundation. Moayed et al. [10]studied the minimum settlement which has testedvarious pile arrangements under different vertical stresslevels. The results show that the arrangements of shortand long piles become more effective when verticalstress on the raft increases.

\section{Literature review}

A comprehensive search was conducted to review theexisting literature on pile structures and pileslabstructure-supported embankments. The literature reviewincludes two parts. Detailed discussions on the two partsare presented below.

\subsection{Pile structure-supported embankments}

In the past few years, pile structure-supported embankments

have been increasingly researched and adopted. Fornumerical simulations, Tan et al. (2008) presented a 2Dnumerical model with pile walls and simulated the dissipationof excess pore water pressure in a stone column reinforced soft foundation under an embankment. Shenand Wang (2016) set up a three-dimensional 
simulationmodel of a CFG pile composite foundation to investigatethe influence of different cushion thicknesses on the deformationof the CFG pile composite foundation. Moayed

et al. (2013) studied the settlement distributions of a compositepiled raft with various pile arrangements under differentvertical stress levels. The results of their studiesshowed that the arrangements of short and long pilesbecome more effective when the vertical stress on the raft

is increased. Huang et al. (2005) modelled a real existingreinforced pile-supported embankment in Berlin and comparedtheir results with those of field measurements. Thevertical and lateral displacements, the tension along the

reinforcement, and the axial forces on the piles were presented.Smith and Filz (2007) illustrated drained axisymmetricnumerical analyses using a mesh of linear elasticzones (to represent the reinforcement). Such analyses

produce results in good agreement with instrumentation data and analytical solutions. Abusharar et al. (2009) investigated the consolidation behaviour of a road embankment constructed on a multi-column composite foundation using a finite element analysis. It was concluded from their study that a multi-column composite foundation allows for a fast rate of consolidation and significantly increases the embankment stability.

Chen et al. (2008a, 2008b) conducted model tests to investigate the soil arching mechanism in embankments with and without reinforcement. The tests indicated that the stress concentration ratio varied with the pile-soil relative displacement. A higher ratio of embankment height to cap beam clear spacing would result in a higher stress concentration ratio. Hironaka et al. (2008) investigated the soil arching modes in model tests using advanced computed tomography technology. Fagundes et al. (2017) performed a series of twenty-eight centrifuge tests on pile-reinforced embankments to assess the influenceof pile spacing, embankment height, pile cap size, and pilestiffness on the load transfer mechanism and surface settlements.Svano et al. (2000) proposed soil wedge modelsto simulate soil arching in embankments supported bypiles. Jenck (2008) conducted 2-D physical experimentson a small-scale model simulating a granular platformover soft soil improved with vertical stiff piles. The experimentsrevealed the load transfer mechanisms and clarifiedthe arching in the platform, settlement reduction, andhomogenization.

\subsection{Pile-slab structure-supported embankments}

Pile-slab structures are mainly composed of concrete

piles, cushions and a concrete slab. The slab is meant to distribute the relative horizontal loads between the soil and the piles. These structures can significantly reduce the settlements of soft foundations under high-speed railway embankments. Thus, they have been increasingly researched and adopted in recent years. Okyay et al., (2012) presented a numerical analysis to analyse the impedance functions of slab foundations with rigid piles. They founded stress-change laws for rigid piles. Yan Jiang et al. (2014) conducted a parametric study of a wellmonitored pile-slab-supported embankment for a high-speed railway to investigate the settlement, the load distribution between the soil and the piles, the structural design parameters, and the excess pore pressure. Messioud et al. (2016a, 2016b) presented a comparison between rigid piles and pile foundations.

They concluded that the mattress stiffness, the geometrical configuration, and the head/tip fixity conditions all had an important influence on the dynamic response of the foundation system. Han and Bhandari (2012) used the discrete element method to numerically simulate the stress

and deformation of geogrid-reinforced embankments over

piles. They found that the settlements of geogridreinforced

embankments over piles were 20-30\% smaller than conventional pile-supported embankments. Messioud et al. (2016a, 2016b) presented a 3D finiteelement model for the dynamic analysis of a soil-pile slab for identifying the influence of mattress stiffness and the pile-soil contact conditions on the dynamic response of the foundation system. Kim (2009) utilized SLOPILE software to design a piled bridge abutment reinforced by a piled slab at a real site. It was concluded that the piled slab could effectively prevent the lateral flow of the soft ground due to the placement of backfill and could satisfy not only the safety factor of a slope, but also the allowable bearing capacity of the piles. Zheng et al. (2013) established a 3-D FE model for an abutment pile foundation to investigate the behaviour of piled bridge abutments which were caused by the compression and $1460 \mathrm{D}$. Zhang et al. / Soils and Foundations 58 (2018) 1458-1475 horizontal displacement of the soft substratum due to the embankment load. Zhan et al. (2013) researched the dynamic deformation characteristics of pile-slab structures by carrying out indoor dynamic model tests. They concluded that the piles expanded the depth of the dynamic response of the foundation and improved the stress of the foundation soil.

According to the above reviews, it can be summarizedthat the studies on pile-slab structure-supported 
embankmentswere mainly focused on the structure patterns, themechanical characteristics, and the settlement distributions.

However, there are no corresponding clear guidelinesfor pile-slab structures for high-speed railways. Theoreticalresearch is seriously lagging behind engineering practice.The bearing capacities of concrete piles cannot be fullymobilized up to the failure of pile-slab structures. In orderto improve pile-slab structures, limited engineering practiceand studies have been conducted on CFG pile-slabstructure-supported embankments. However, the mechanismsinvolving soil-pile-slab interactions are not clearfor high-speed railways. The settlement-controlling effect,the settlement distribution, and the optimized structuralform of CFG pile-slab structures should be investigatedthoroughly with respect to their application to high-speedrailways.

\section{Research object}

A map of the Beijing-Shanghai high-speed railway isshown in Fig. 3 (Baike, 2013). The part of this railway fromSuzhou to Kunshan was selected for application of the proposedCFG pile-slab structure. This part of the railway wasconstructed on a large area of soft soil foundation, whichhas a low bearing capacity and is also prone to largesettlements.Fig. 1(a) and (b) shows the floor plan view and the crosssectionalview of this area, respectively, for use of the CFGpile-slab structure. The railway embankment is $6.25 \mathrm{~m}$ highwith $1(\mathrm{~V}): 1.5(\mathrm{H})$ side slopes. The depth of the investigatedarea is $25 \mathrm{~m}$ and the width is $50 \mathrm{~m}$. The material of theembankment fill is well-graded sandy soil. A reinforcedconcrete slab, $0.8 \mathrm{~m}$ in thickness, is constructed under theembankment fill. Concrete piles are directly connected tothe edge of the concrete slab, while CFG piles are coveredwith a cushion, $0.2 \mathrm{~m}$ in thickness. The piles are $15 \mathrm{~m}$ inlength.

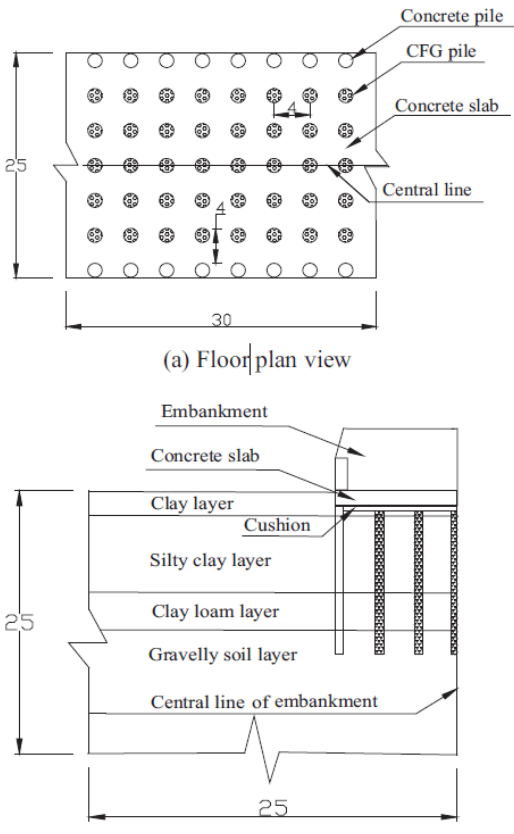

(b) Cross-sectional view

The main mechanism of the CFG pile-slab structure isthe transfer of vehicle loads from the slab to the pilesthrough a layer of sand cushion. The piles further help tospread the load to the soil between the piles and the softfoundation. The interaction among the pile groups, theslab, and the soil forms a system, which can help to reducethe ettlements of the embankment. The strengtheningmechanism of the CFG pile-slab structuresupportedembankment can be summarized in the form of pile effects(replacement, compaction, and reinforcement) as well asslab effects (adjusting and homogenizing the upper loads).

With the increase in vehicle loads, more loads get transferredfrom the soil to the piles. While more loads transferto the piles, smaller loads will be assigned to the soil. Forthe friction pile group, the sinking of the bearing slab couldcause the soil to sink. This will then bring about the furthertransfer of loads from the bearing slab to the piles. The pilesettlements will increase due to the increased load, whichwill further cause compressive force between the soil andthe piles. Pile penetration, deformation, and compressionof the soil between the piles are subjected to this cyclicprocess.

In real practice, $\mathrm{CFG}$ piles are installed at a depth of $15 \mathrm{~m}$ (i.e., deeper than soft soil layers). The other soil layersare extended to a depth of nearly $90 \mathrm{~m}$. In the loading system,based on the scaling laws, the size of the simulatedstructure is 10 times smaller than the real structure. Inorder to decrease the boundary effect of the 
studied area,the size of the area is kept much larger than the loadingarea. Therefore, the length, width, and height are set at $3.25 \mathrm{~m}, 1.25 \mathrm{~m}$, and $2.5 \mathrm{~m}$, respectively. These are fourtimes larger than the loading area. The front and back sidesof the box are embedded with tempered glass, $12 \mathrm{~mm}$ inthickness, and a smooth iron plate, $8 \mathrm{~mm}$ in thickness

This dynamic loading system is composed of a reactionbeam, a vertical reaction frame, a hydraulic jack, a forcegauge, and a loading plate. The loading system helps totransfer the external loads to the top of the physical model.

The loads on the slab are composed of embankment weight

and vehicle forces, which are considered to be uniformlydistributed loads. The hydraulic jack exerts the simulatedloads on the model through the loading plate. The valueof the simulated loads varies between zero and the maximumtest load. According to the scaling laws, these simulatedloads are about two orders in magnitude smallerthan the actual design loads of high-speed railways. Therefore,the loading system can simulate the varying stressexerted due to high-speed trains on the embankment foundation.

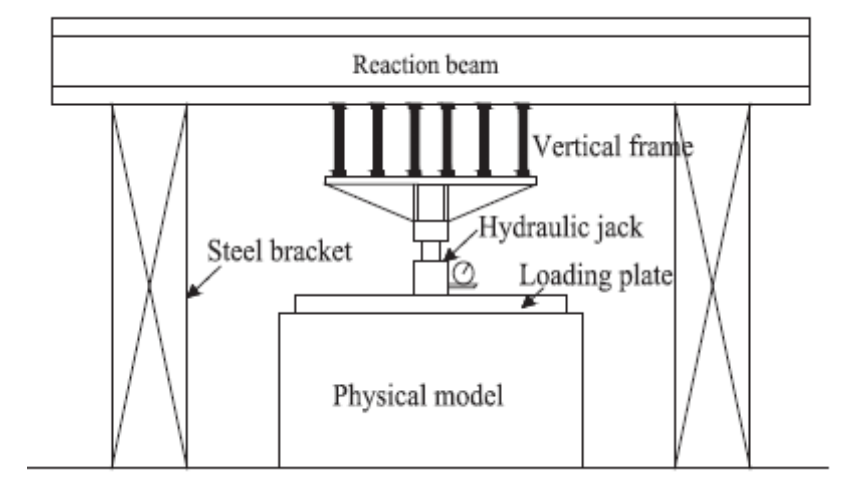

It can be observed from that the maximumsettlements of the single CFG pile and the concretepile are $6.2 \mathrm{~mm}$ and $5.2 \mathrm{~mm}$, respectively. This correspondsto the case when the external load per unit is $350 \mathrm{kPa}$. Thetwo types of piles are still in the elastic deformation stage.It can be concluded that the bearing capacities of the singleCFG pile and the single reinforced concrete pile are bothsufficient to resist the maximum load per unit area byhighspeed trains. Under the same external loads, the settlementsof CFG piles are larger than those of concretepiles because of the smaller deformation modulus. Thebearing capacities of both piles are more than the maximumexternal pressure exerted by high-speed trains. However,after unloading, the resilience rate of both pilesdecreases. This is because of the compression of the cushionand the pile-bearing layer under external pressure.

A comparative analysis among the settlement of the naturalfoundation, the CFG pile composite foundation, andthe CFG pile-slab structure-reinforced foundation It can be observed that the maximum settlementof the natural foundation is much larger than that of eitherthe CFG composite foundation or the CFG pile-slab structure.It can be noticed that when the external load per unitis $300 \mathrm{kPa}$, the CFG pile-slab structure is able to reduce thesettlement of the natural foundation from $93.8 \mathrm{~mm}$ to $34.7 \mathrm{~mm}$. Under this load, the settlement of the CFG compositefoundation is $52.6 \mathrm{~mm}$ and when the stress is smaller than $175 \mathrm{kPa}$, the settlement ofthe CFG composite foundation is nearly the same as thatof the CFG pile-slab structure. This is because of the distributioneffect of the slab that causes the pile-soil stress ratioof the CFG composite foundation to be larger than that ofthe CFG pile-slab structure.Under this, more external loadis distributed on the piles. It can be concluded that thesettlement-controlling effect of the CFG pile-slab structureon a soft soil foundation is remarkable.

\section{References}

1. Abusharar, S.W., Zheng, J.J., Chen, B.G., 2009. Finite element modelling of the consolidation behavior of multi-column supported road embankment. Comput. Geotech. 36 (4), 676-685.

2. Baike 360 soso online, 2013 May 20. Beijing, Chinese 360 Limited

3. Company. https://baike.so.com/ (accessed 2018 May 10).

4. BS 8006-1, 2010. British Standard Code of Practice for Strengthened/

5. Reinforced Soils and Other Fills. British Standard Institution, London, Britain. 
6. Chen, Y.M., Cao, W.P., Chen, R.P., 2008b. An experimental investigation of soil arching within basal reinforced and unreinforced piled embankments. Geotext Geomembr. 26 (2), 164-174.

7. Chen, R.P., Chen, Y.M., Han, J., 2008a. A theoretical solution for pilesupported embankments on soft soils under one-dimensional compression. Can. Geotech. J. 45 (5), 611-623.

8. Collin, J.G., 2007. State-of-practice for the design of the geosynthetic reinforced load transfer platform in column supported embankments.

9. In: Proceedings of GeoDenver, Denver, Colorado, USA

10. Fagundes, D.F., Almeida, M.S.S., Thorel, L., Blanc, M., 2017. Load transfer mechanism and deformation of reinforced piled embankments. Geotext Geomembr. 45 (2), 1-10.

11. Gerolymos, N., Gazetas, G., 2005. Phenomenological model applied tominelastic response of soil-pile interaction systems. Soils Found. 45 (4), 119-132.

12. Han, J., Bhandari, A., 2012. DEM analysis of stresses and deformations of geogrid-reinforced embankments over piles. Int. J. Geomech. 12 (4), 340-350.

13. Hen, Q., Zhao, M., Zhou, G., 2008. Bearing capacity and mechanical behavior of CFG pile composite foundation. J. Cent. South Univ. 15 (s2), 45-49.

14. Hironaka, J., Hirai, T., Otani, J., Watanabe, Y., 2008. Load transfer mechanism in reinforced embankment on pile elements. In: Otani,

15. Miyata, Mukunoki, (Eds.), . In: New Horizons in Earth Reinforcement.

16. Taylor and Francis Group, London, British.

17. Huang, J., Han, J., Collin, J., 2005. Geogrid-reinforced pile-supported railway embankments: a threedimensional numerical analysis. Transport. Res. Rec. 1936 (1), 221-229.

18. Huang, Q., Liu, F., 2016. Research on Pile-sheet Structure of Loess

19. Subgrade in Passenger Railway Line from Baoji to Lanzhou. J. Lan. Ins. T. 23 (5), 15-18 (in Chinese).

20. Jenck, O., Dias, D., Kastner, R., 2009. Discrete element modelling of granular platform supported by piles in soft soil-validation on a small scale model test and comparison to a numerical analysis in a continuum. Comput. Geotech. 36 (6), 917-927.

21. Kim, T.H., 2009. Estimation of the effect of lateral flow on piled bridge abutments in soft ground considering piled slabs as a countermeasure of the abutments. Mar. Georesour. Geotech. 27 (1), 34-52.

22. Messioud, S., Sbartai, B., Dias, D., 2016b. Estimation of dynamic impedance of the soil-pile-slab and soilpile-mattress-slab systems. Int. J. Struct. Stab. Dy. 17 (6), 1-17.

23. Messioud, S., Okyay, U.S., Sbartai, B., et al., 2016a. Dynamic response of pile reinforced soils and piled foundations. Geotech. Geolog. Eng. 34 (3), 789-805.

24. Moayed, R.Z., Izadi, E., Mirsepahi, M., 2013. 3D finite elements analysis of vertically loaded composite piled raft. J. Cent. South Univ. 20 (6), 1713-1723.

25. Okyay, U.S., Dias, D., Billion, P., Vandeputte, D., 2012. Impedance Functions of Slab Foundations with Rigid Piles. Geotech. Geolog. Eng. 30 (4), 1013-1024.

26. Raithel, M., Kirchner, A., Kempfert, H.G., 2008. German recommendations for reinforced embankments on pile-similar elements. Geosynthetics in Civil and Environmental Engineering. Springer-Verlag, Berlin, Heidelberg, Germany.

27. Raychowdhury, P., Hutchinson, T.C., 2010. Performance evaluation of a nonlinear Winkler-based shallow foundation model using centrifuge test results. Earthquake Eng. Struct. 38 (5), 679-698. 1474 D. Zhang et al. / Soils and Foundations 58 (2018) 1458-1475

28. Reza, Z.M., Ehsan, I., Mehrad, M., 2013. 3D finite elements analysis of vertically loaded composite piled raft. J. Cent. South Univ. 20 (6), 1713-1723.

29. Russell, D., Pierpoint, N., 1997. An assessment of design methods for piled embankments. Ground Eng. 30 (10), 39-44.

30. Shen, Y., Wang, H., 2016. Optimization design on CFG-pile foundation with different cushion thickness in Beijing-Shanghai high-speed railway. Infrastrut. Geotech. 3 (1), 3-20.

31. Smith, M., Filz, G., 2007. Axisymmetric numerical modeling of a unit cell in geosynthetic-reinforced, column-supported embankments. Geosynth. Int. 14 (1), 13-22.

32. Svano, G., Ilstad, T., Eiksund, G., Want, A., 2000. Alternative calculation principle for design of piles embankments with base reinforcement. In:

33. Proceedings of the 4th International Conference of Ground Improvemen Geosystem, Helsinki, Finland.

34. Tan, S.A., Tjahyono, S., Oo, K.K., 2008. Simplified plane-strain modelling of stone-column reinforced ground. J. Geotech. Geoenviron. Eng. 134 (2), 185-194.

35. TB 10001-2016, 2016. Chinese Standard Code of Design for Road-bed of Railway. Chinese Standard Institution of Railway Administration, Beijing (China).

36. TB 10106-2010, 2010. General Code for Foundation Treatment of Highspeed Railway. Chinese Highway Planning and Design Institute, Beijing, China. 
37. TB, T 3466-2016, 2016. Chinese Standard Code of Railway Train Load Pattern. Chinese Standard Institution of Railway Administration, Beijing, China.

38. Voottipruex, P., Bergado, D.T., Suksawat, T., Jamsawang, P., Cheang, W., 2011. Behavior and simulation of deep cement mixing (DCM) and stiffened deep cement mixing (SDCM) piles under full scale loading. Soils Found. 51 (2), 307-320.

39. Zhan, Y., Yao, H., Jiang, G., 2013. Design method of pile-slab structure roadbed of ballastless track on soil subgrade. J. Cent. South Univ. 20 (7), 2072-2082.

40. Zhang, Y., Cao, Y.Y., 2015. A fuzzy quantification approach of uncertainties in an extreme wave height modeling. Acta Oceanol. Sin. 34 (3), 90-98.

41. Zhang, Y., Kim, C.W., Tee, K.F., Lam, J.S.L., 2017b. Optimal sustainable life cycle maintenance strategies for port infrastructures. J. Clean. Prod. 142, 1693-1709.

42. Zhang, Y., Kim, C.W., Beer, M., Dai, H., Guedes, S.C., 2018. Modeling multivariate ocean data using asymmetric copulas. Coast. Eng. 135, 91-111.

43. Zhang, F., Kimura, M., 2002. Numerical prediction of the dynamic behaviors of an RC group-pile foundation. Soils Found. 42 (3), 77-92.

44. Zhang, Y., Lam, J.S.L., 2016. Estimating economic losses of industry clusters due to port disruptions. Transport. Res. Part A: Policy Pract. 91, 17-33.

45. Zhang, D.B., Zhou, C.B., Liu, Y.B., Yuan, J.Y., 2014. Study on themsimilar material characteristics for model test based on daye iron mine. J. Chem. Phar. Res. 6 (3), 1330-1336.

46. Zhang, D.B., Zhang, Y., Cheng, T., Meng, Y., Fang, K., Ankit, G., et al.,m2017a. Measurement of displacement for open pit to underground mining transition using digital photogrammetry. Measurement 109 (10), 187-199.

47. Zheng, J.L., Zhang, J.H., Li, X.F., 2013. Effects of embankment load on piled bridge abutments on soft clay. China J. H. Trans. 26 (2), 48-55(in Chinese). 